JURNAL SISFOTENIKA

Vol. 10 No. 1, Januari 2020

p-ISSN: 2087-7897 ; e-ISSN : 2460-5344

DOI : $10.30700 /$ jst.v10i1.947

\title{
Penerapan Jaringan Syaraf Tiruan Backpropagation Dalam Sistem Pakar Diagnosa Virus TORCH
}

\section{Application of Backpropagation Artificial Neural Networks in the TORCH Virus Diagnosis Expert System}

\author{
Erwin Gunawan Walker ${ }^{1}$, David ${ }^{2}$ \\ Teknik Informatika STMIK Pontianak: Jl. Merdeka No. 372, Pontianak 78111 \\ Jurusan TeknikInformatika, STMIK Pontianak \\ e-mail: erwin_g_walker@yahoo.com,davidliauw@gmail.com
}

\begin{abstract}
Abstrak
Virus TORCH merupakan singkatan dari virus Toxoplasma, Rubella, Cytomegalo Virus, dan Herpes. Virus TORCH menyebabkan banyak anak yang terlahir cacat. Tujuan dari penelitian ini adalah untuk menghasilkan dan membangun sebuah perangkat lunak sistem pakar yang dapat membantu penderita dalam melakukan diagnosa awal terhadap virus TORCH, agar dapat mengurangi resiko anak yang terlahir cacat yang disebabkan oleh virus ini. Bentuk metode penelitian adalah studi kasus dan wawancara dalam mencari tahu tentang virus TORCH. Pembuatan sistem pakar ini menggunakan Visual Basic .NET dalam pembuatan aplikasinya. Sistem pakar yang digunakan adalah forward chaining yang dipadankan dengan jaringan syaraf tiruan Backpropagation sebagai pengambilan keputusan. Sistem pakar ini menampilkan pilihan gejala yang dapat dipilih user, dimana setiap pilihan gejala akan membawa user kepada pilihan gejala selanjutnya sampai mendapatkan hasil akhir. Sedangkan database yang digunakan adalah menggunakan MySql. Model perancangan yang digunakan adalah UML (Unfield Modeling Language) dan flowchart. Metode perancangannya adalah prototype dan pengujian perangkat lunak menggunakan black box untuk menguji sistem yang telah dibangun. Hasil penelitian ini adalah dapat membantu masyarakat agar dapat lebih memahami dan mengetahui virus TORCH yang diderita sehingga dapat segera diobati untuk menghindari anak yang terlahir cacat. Saran kedepannya adalah agar sistem pakar ini dapat bersifat online.
\end{abstract}

Kata kunci : Sistem Pakar, Backpropagation, Forward Chaining, Virus TORCH

\begin{abstract}
Virus TORCH is an acronym of the virus Toxoplasma, Rubella, Cytomegalo virus, and Herpes. TORCH virus causes many children born with disabilities. The purpose of this study is to generate and build an expert system software that can help the patient in making an early diagnosis of the TORCH virus, in order to reduce the risk of children born with disabilities caused by this virus. Method research design is a case study and interviews in finding out about the TORCH virus. This expert system making use of Visual Basic.NET in the making of the application. An expert system is paired with a forward chaining neural network Backpropagation as decision-making. This expert system featuring a large selection of symptoms that can be selected user, where each choice of symptoms will bring the user to the selection of the next symptom to get the final result. While the database used is MySQL. Design model used is UML (Unfield Modeling Language) and flowchart. Its design method is a prototype and testing software using black box testing systems have been built. The results of this study is to help the public to better understand and know TORCH suffered virus so that it
\end{abstract}


can be treated promptly to avoid the children who are born with disabilities. Suggestions in the future is that this expert system can be online

Keywords : Expert System, Backpropagation, Forward Chaining, TORCH Virus

\section{PENDAHULUAN}

Sistem pakar adalah sistem yang berusaha mengadopsi pengetahuan manusia ke komputer, agar komputer dapat menyelesaikan masalah seperti yang biasa dilakukan oleh para ahli [4]. Sistem pakar terdiri dari dua bagian yang harus dimiliki yaitu knowledge base dan inference engine. Knowledge base adalah sebuah database yang menyimpan informasi pengetahuan tertentu dan aturan-aturan tentang subjek tertentu, sedangkan inference engine adalah bagian dari sistem pakar yang mencoba menggunakan informasi yang diberikan untuk menemukan objek yang sesuai.

Komponen sistem pakar yaitu antar muka pengguna (user interface), basis pengetahuan (knowledge base), mesin inferensi(inference machine), memori kerja (working memory),workplace, fasilitas penjelasan dan perbaikan pengetahuan.Salah satu implementasi yang diterapkan sistem pakar dalam bidang kesehatan yaitu sistem pakar untuk diagnosa virus TORCH. virus TORCH adalah singkatan dari Toxoplasma, Rubella, Cytomegalo Virus, dan Herpes. Virus TORCH merupakan virus yang dapat menyebabkan anak terlahir cacat bila ibu yang sedang hamil terinfeksi virus ini. Gejala virus TORCH pada awalnya seperti demam, batuk pilek, dan lain-lain. Sehingga pada ibu hamil dapat mewaspadai pada gejala yang terjadi pada mereka. Agar tidak ada kesalahan diagnosa dan untuk mempermudah masyarakat atau penderita mengetahui sejak dini penyakit yang diderita sehingga tidak terlambat mendapatkan pengobatan. Penggunaan jaringan syaraf tiruan Backpropagation digunakan dalam sistem pakar ini.

Penelitian sebelumnya mengusulkan sebuah sistem pakar dengan menggunakan jaringan syaraf tiruan Backpropagation untuk mendiagnosa penyakit kulit. Sistem pakar ini mendiagnosa dengan mengambil gambar kulit seseorang yang akan di diagnosa dan kemudian di bandingkan dengan database. Berdasarkan gambar tersebut dapat diketahui apakah penyakit kulit yang diderita orang tersebut [1]. Penelitian lainnya adalah mendiagnosa penyakit gigi. Pengujian dilakukan dengan mengambil 50 sampel data yang belum pernah dilatih hasil menunjukan bahwa 45 dari 50 (90\%) data yang diuji dapat dikenali oleh sistem [2]. Berikutnya adalah diteksi pengeroposan tulang dengan membandingkan hasil gambar $x$-ray. Sistem kerja di dalam perangkat lunak ini meliputi 3 pemrosesan penting, yaitu proses pengolahan citra dasar, prosesreduksi piksel, dan proses jaringan syaraf tiruan dalam mendiagnosa [3].

Penelitian ini menggunakan metode pencarian menggunakan forward chaining. Forward chaining merupakan teknik pelacakan ke depan yang dimulai dengan informasi yang ada dan penggabungan rule untuk menghasilkan suatu kesimpulan atau tujuan. Sistem ini akan menampilkan pilihan gejala yang dapat dipilih oleh user, dimana setiap pilihan gejala akan membawa user kepada pilihan gejala selanjutnya sampai mendapatkan hasil akhir.Penelitian ini juga menggunakan metode jaringan syaraf tiruan backpropagation sebagai penalaran pencarian solusi.

\section{METODE PENELITIAN}

Penelitian ini berbentuk survey, yaitu mencatat gejala dan solusi virus TORCH dari pakar. Pengumpulan data dilakukan dengan melakukan studi dokumentasi dan observasi. Hasil dari studi dokumentasi dan observasi diagnose virus TORCH dikumpulkan dan menjadi sampel yang digunakan sebagai bahan inferensi jaringan syaraf tiruan. Metode perancangan perangkat 
lunak menggunakan prototype dengan pendekan UML (Unfield Modeling Language) dan flowchart.

Untuk metode pengujiannya adalah menggunakan pengujian black-box yaitu pengujian memungkinkan perekayasa perangkat lunak mendapatkan serangkaian input yang sepenuhnya menggunakan semua persyaratan fungsional untuk suatu program. Pembuatan aplikasi inimenggunakan Visual Basic .net dengan basis data MySql. Analisis dan perancangan aplikasi dalam penelitian ini menggunakan model UML dan flowchart, untuk tahap analisis, metode ini memeriksa kebutuhan yang harus dipenuhi sebuah sistem dan menganalisis data-data yang diperlukan dalam sistem yang dirancang, sedangkan untuk tahap desain, metode ini memfokuskan pada desain pembuatan program perangkat lunak termasuk struktur data, dan arsitektur perangkat lunak [7]. Metode pengujian menggunakan pengujian blackbox yaitu pengujian dimaksudkan untuk mengetahui apakah fungsi-fungsi, masukan dan keluaran dari perangkat lunak sesuai dengan spesifikasi yang dibutuhkan[7].

\section{HASIL DAN PEMBAHASAN}

Pada penelitian ini, dilakukan indentifikasi kebutuhan yang di perlukan dalam mengembangkan sistem pakar diagnosa virus TORCH. Agar sistem pakar yang di rancang dapat lebih terarah dalam mendiagnosa seorang ibu hamil, maka perlu dilakukan indetifikasi kebutuhan. Idetifikasi kebutuhan fungsional (functional requirement) adalah kebutuhan yang berkaitan dengan fungsi atau proses transformasi yang mampu dikerjakan oleh sistem pakar. Dimana sistem pakar diagnosa virus TORCH dapat dapat memberikan beberapa fungsi seperti:

a Sistem pakarmampu menampilkan formyang akan digunakan dalam mendiagnosa seseorang.

b Sistem pakarmampu menampilkan pertanyaan yang akan digunakan dalam mendiagnosa.

c Sistem pakar mampu melakukan inisialisasi struktur dan bobot jaringan saraf tiruan (JST) dan melakukan pelatihan jaringan syaraf tiruan (JST) untuk mengenal pola gejala virus TORCH.

d Sistem pakar mampu memberikansolusi yang didapat dari jawaban user, yang telah diproses oleh sistem pakar.

Terdapat beberapa bagian pada arsitektur sistem pakar yang dirancang pada sistem ini diantaranya adalah basis data, basis pengetahuan, akuisisi pengetahuan, mesin inferensi, jaringan syaraf tiruan Backpropagation, pengguna dan pakar(gambar 1). 


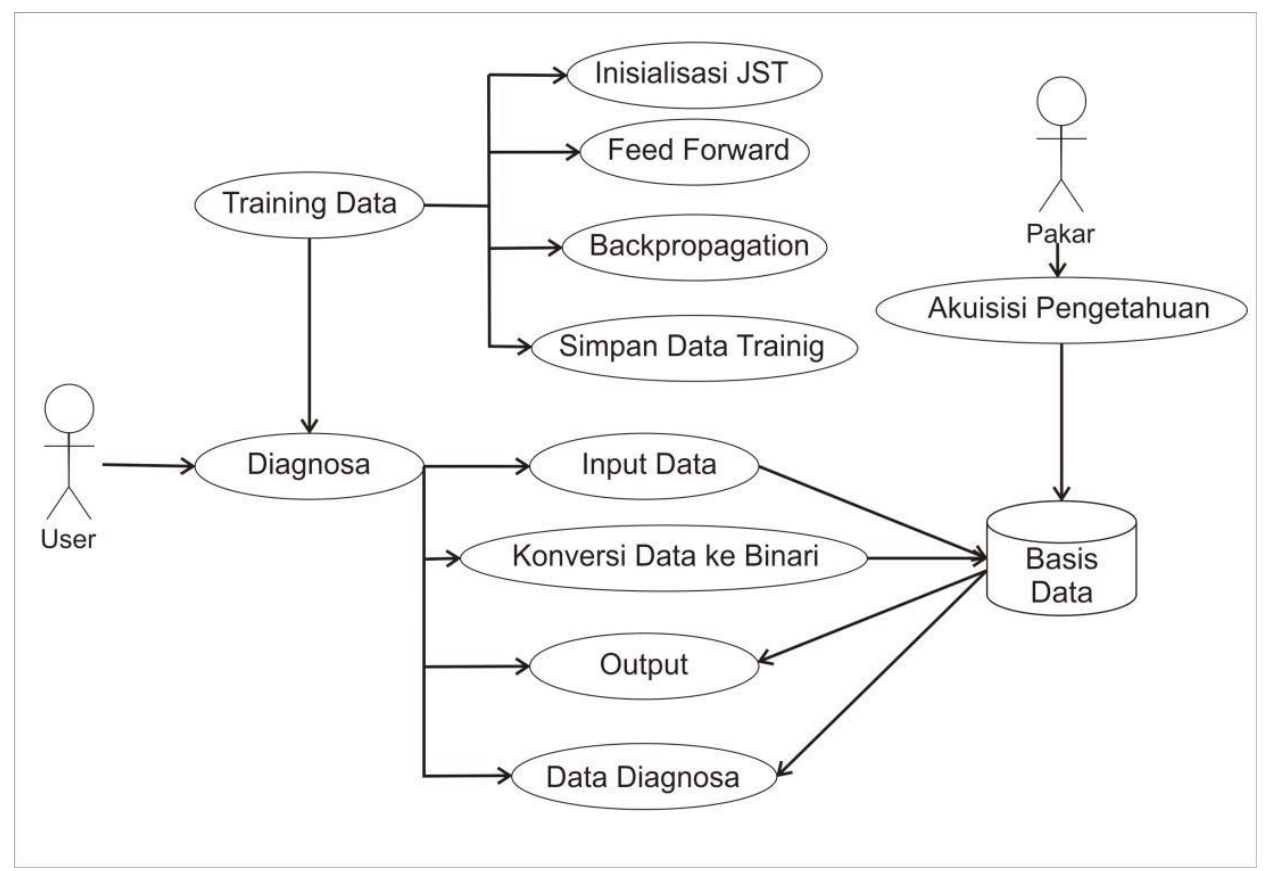

Gambar 1. Arsitektur Sistem Pakar

Dari gambar diatas (Gambar 2) memperlihatkan gambaran umum dari sistem pakar diagnosa virus TORCH. Gambar arsitektur di atas menunjukansistem pakar akanmelakukan training data. Di dalam training data terdapat beberapa proses, yaitu backpropagation, feedforward, inisialisasi jaringan syaraf tiruan, dan simpan data training. Setelah itu, userakan memulai diagnosa. Dimana sistem pakar akan memberikan beberapa pertanyaan.Dari pertanyaan tersebut, user akan memberikan input yang sesuai dengan pertanyaan dari sistem pakar. Dari input yang diberikan user, sistem pakar mulai mendiagnosa dan selajutnya data di teruskan ke basis data. Dimana basis data berisikan akuisisi pengetahuan yang telah didapat dari seorang pakar atau dokter kandungan untuk mendiagnosa dan memberikan solusi. Solusi tersebut akan menjadi output yang akan ditampilkan kepada user. Pada saat diagnosa selesai, maka sistem pakar akan menimpan data diagnosa dan data tersebut dapat dilihat kembali oleh user.

Untuk melihat garis besar dari sistem pakar diagnosa virus TORCH secara fungsional, maka dibuatlah sebuah diagram use case. Use case didokumentasikan menggunakan use case diagram tingkat tinggi, Himpunan use case mewakili semua interaksi yang mungkin akan dijelaskan dalam kebutuhan sistem. Aktor dalam proses, yang mungkin manusia atau sistem lainnya direpresentasikan sebagai stick figure. Setiap kelas interaksi direpresentasikan sebagai clips yang diberi nama. Garis menghubungkan aktor dengan interaksi. Secara fakultatif, panah dapat ditambahkan ke garis untuk menunjukkan bagaimana interaksi dimulai. 


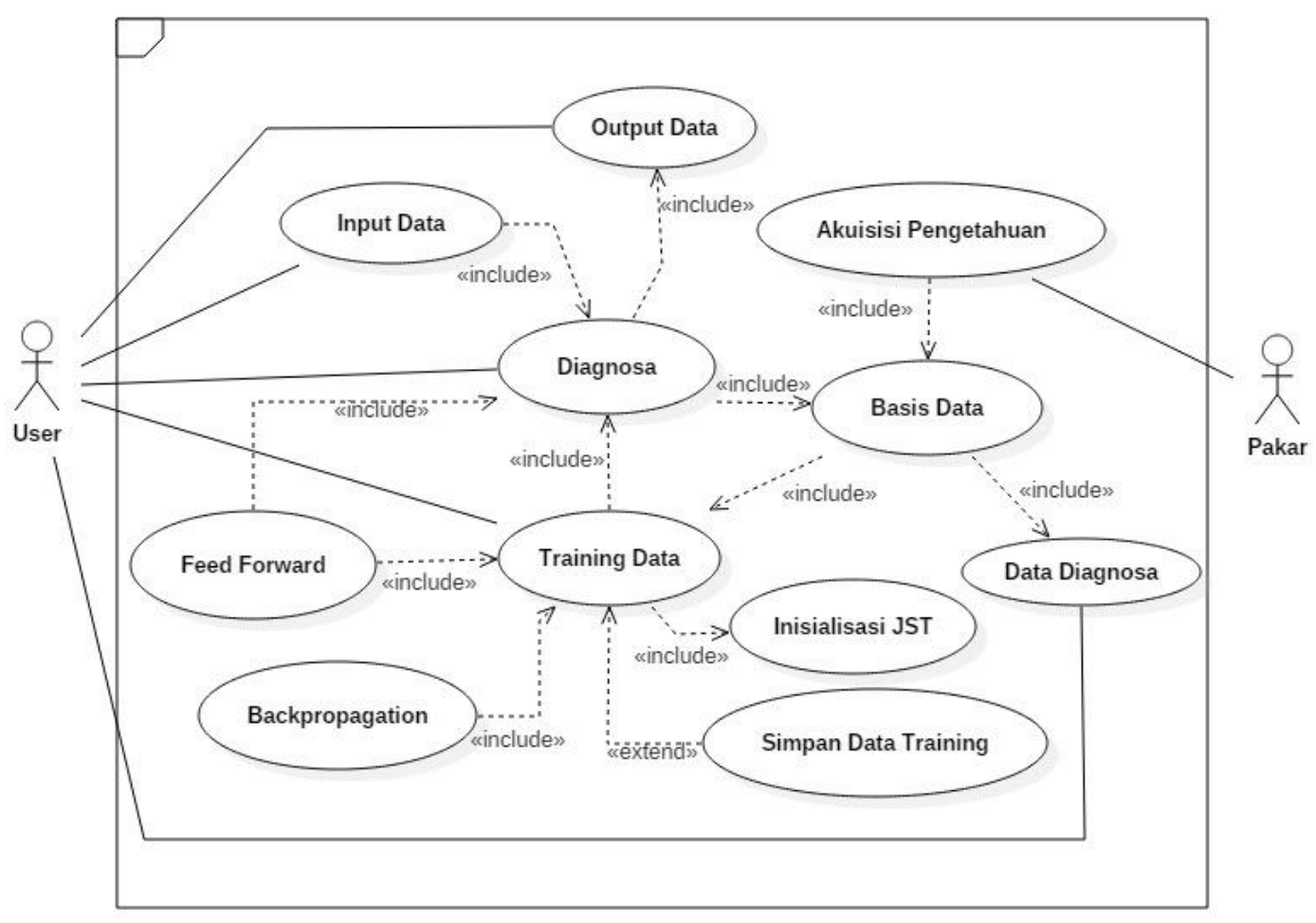

Gambar 2. Diagram Use caseSistem Pakar Diagnosa Virus TORCH

Pada gambar diagram use case di atas menunjukan cara kerja sistem pakar diagnosa virus TORCH. Saat user menggunakan sistem pakar diagnosa virus TORCH, input data yang diberikan oleh user akan diproses menuju diagnosa, dan pada bagian training data akan memproses pola-pola yang pernah terjadi sebelumnya. Setelah itu semua data diteruskan ke basis data untuk memperoleh hasil. Dimana hasil tersebut berasal dari perbandingan dengan data akuisisi pengetahuan yang di dapat dari seorang pakar. Kemudian dari hasil tersebut akan menjadi output yang akan ditamilkan kepada user, dan data tersebut akan disimpan di dalam data diagnosa supaya user dapat melihat kembalidata yang terdahulu.

Untuk menggambarkan arsitektur sistem pakar diagnosa virus TORCH, maka dibuatlah class diagram. Gambar berikut meupakan class diagram dari sistem pakar diagnosa virus TORCH. Class diagram dapat dianggap sebagai definisi umum dari satu jenis objek sistem. Sebuah asosiasi adalah hubungan antara kelas-kelas yang menunjukkan hubungan antara kelaskelas ini. Oleh karena itu, setiap kelas mungkin harus memiliki beberapa pengetahuan dari kelas yang terkait. Class diagram dalam UML dapat diekspresikan pada tingkat detail yang berbeda. Ketika mengembangkan model, langkah pertama biasanya untuk melihat dunia, mengidentifikasi objek yang penting dan menyajikannya sebagai sebua kelas, Cara termudah untuk menulis ini adalah menulis nama kelas dalam sebuah kotak. Dapat juga dengan hanya mencatat keberadaan sebuah asosiasi dengan menggambar garis antara kelas. 


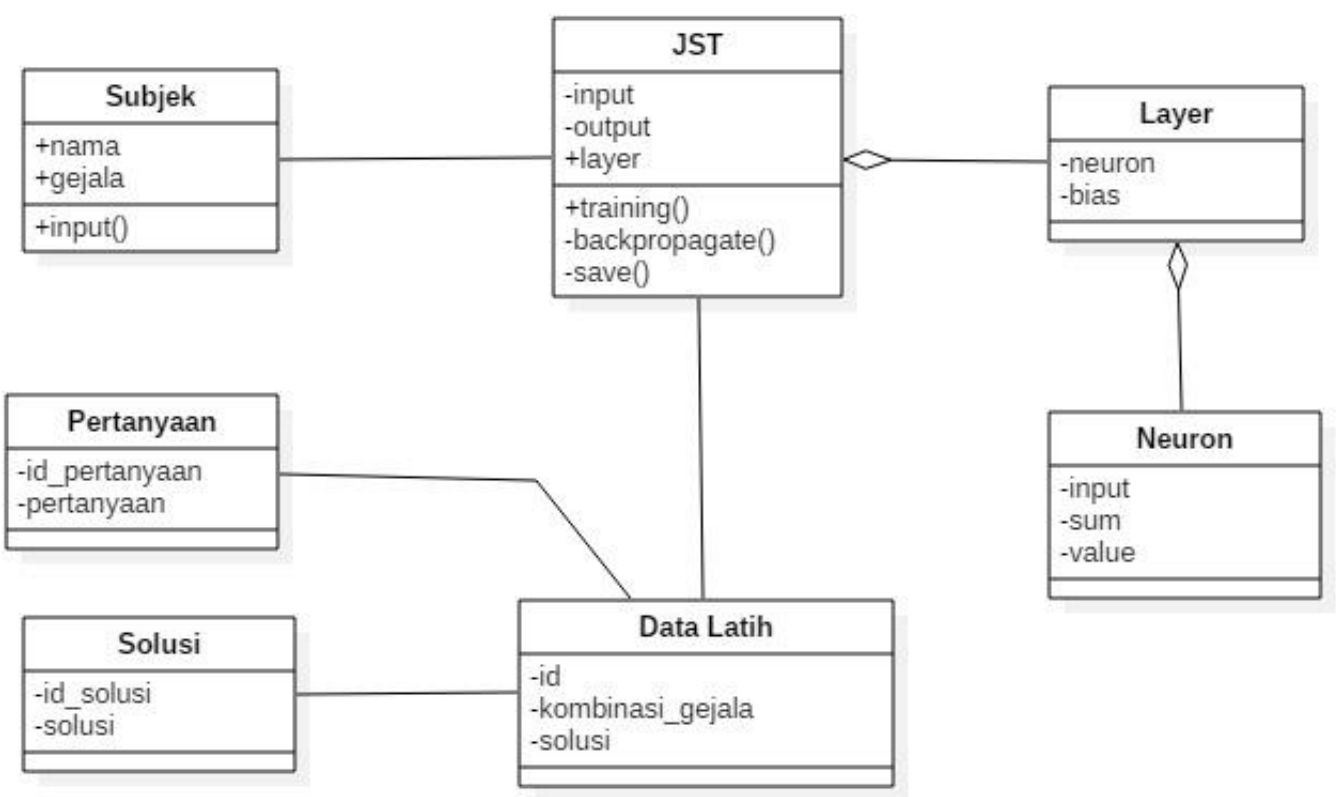

Gambar 3. Class Diagram Sistem Pakar Diagnosa Virus TORCH

Class diagram diatas menunjukan gambaran dari sistem pakar yang sedang dikembangkan. Dalam sistem pakar ini, kelas utamanya adalah kelas jaringan syaraf tiruan yang digunakan untuk mendiagnosa. Kelas jaringan syaraf tiruan tersusuan dari layer, input, dan output. layer merupakan kumpulan dari objek neuron. Sedangkan input dan output berasal dari data latih, dimana data latih berisikan kombinasi gejala yang di dapat dari kelas pertanyaan dan solusi yang di dapat dari kelas solusi.

Setelah melakukan class digram, diagram berikutnya adalah sequence diagram. untuk menggambar diagram sekuen maka harus diketahui objek-objek yang terlibat dalam sebuah use case beserta metode-metode yang dimiliki kelas yang diinstansiasi menjadi objek itu, Membuat diagram sekuen juga dibutuhkan untuk melihan skenario yang ada pada use case. 


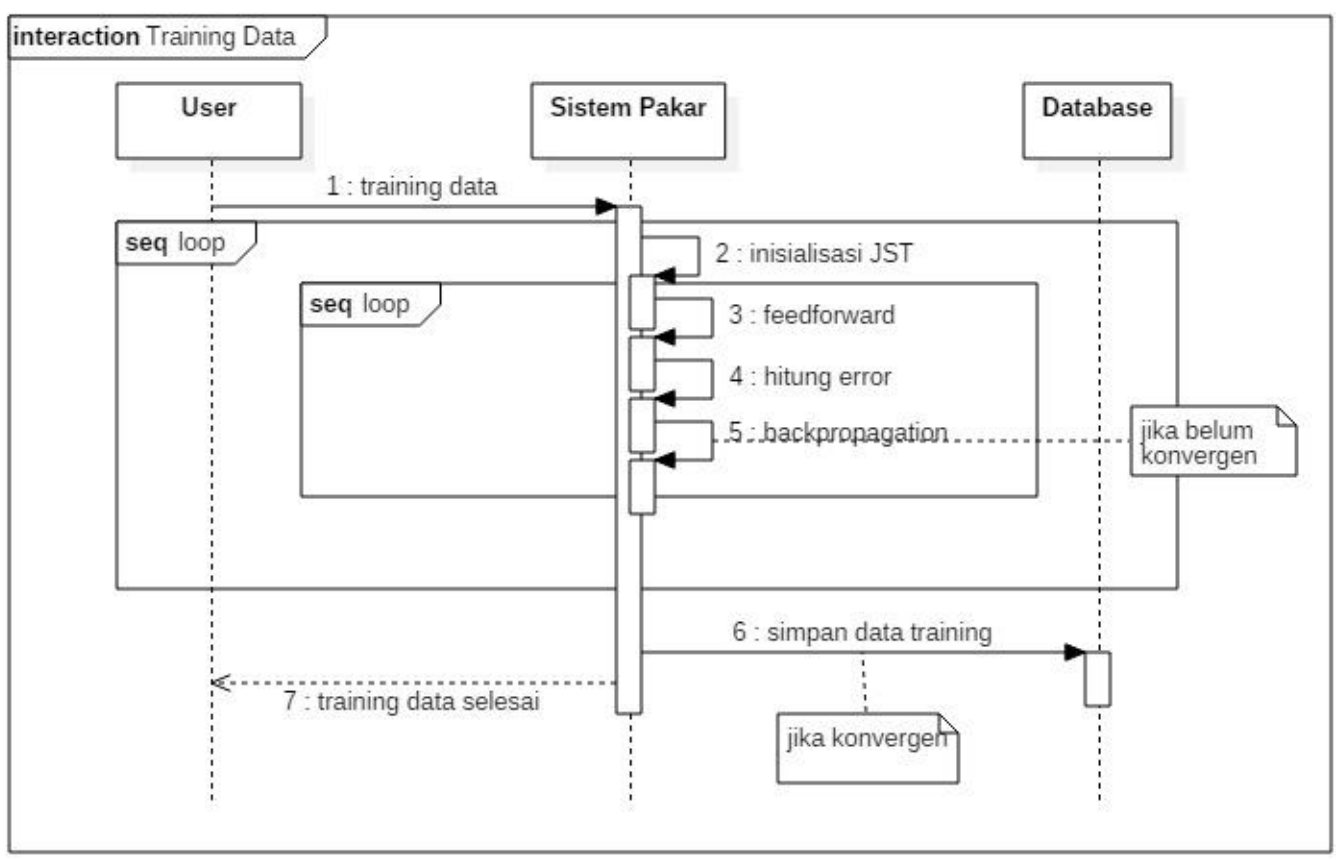

\section{Gambar 4. Sequence Diagram Trainig Data}

Dari sequence diagram trainig data dapat dilihat, user akan melakukan training data sebelum melakukan diagnosa. Proses training data dilakukan dengan melakukan inisialisasi jaringan syaraf tiruan (JST) terlebih dahulu. Proses inisialisasi jaringan syaraf tiruan(JST) dilakukan dengan menginisialisasi beberapa jumlah layer dan neuron yang telah ditentukan bobot awal secara acak. Data akan dipropagasi maju dalam jaringan, kemudian melakukan perhitungan kesalahan yang terjadi. Jika kesalahan diatas ambang toleransi (belum konvergen) sistem akan mengseksekusi backpropagation untuk perbaikan bobot. Jika sudah konvergen, konfigurasi jaringan syaraf tiruan(JST) dan bobot akan di simpan komputer dalam format .NETAK.

Berikutnya adalah proses dari activity diagram. Awal proses ditunjukkan dengan lingkaran tersisi dan di akhir ditunjukkan dengan lingkaran terisi di dalam lingkaran lain. Persegi panjang dengan sudut yang membulat mewakili kegiatan, yaitu sub-proses yang spesifik yang harus dilakukan. UML activity diagram, panah mewakili aliran kerja dari satu aktivitas ke aktivitas lainnya. Panah dapat dijelaskan dengan guards yang menunjukkan kondisi ketika aliran diambil. 


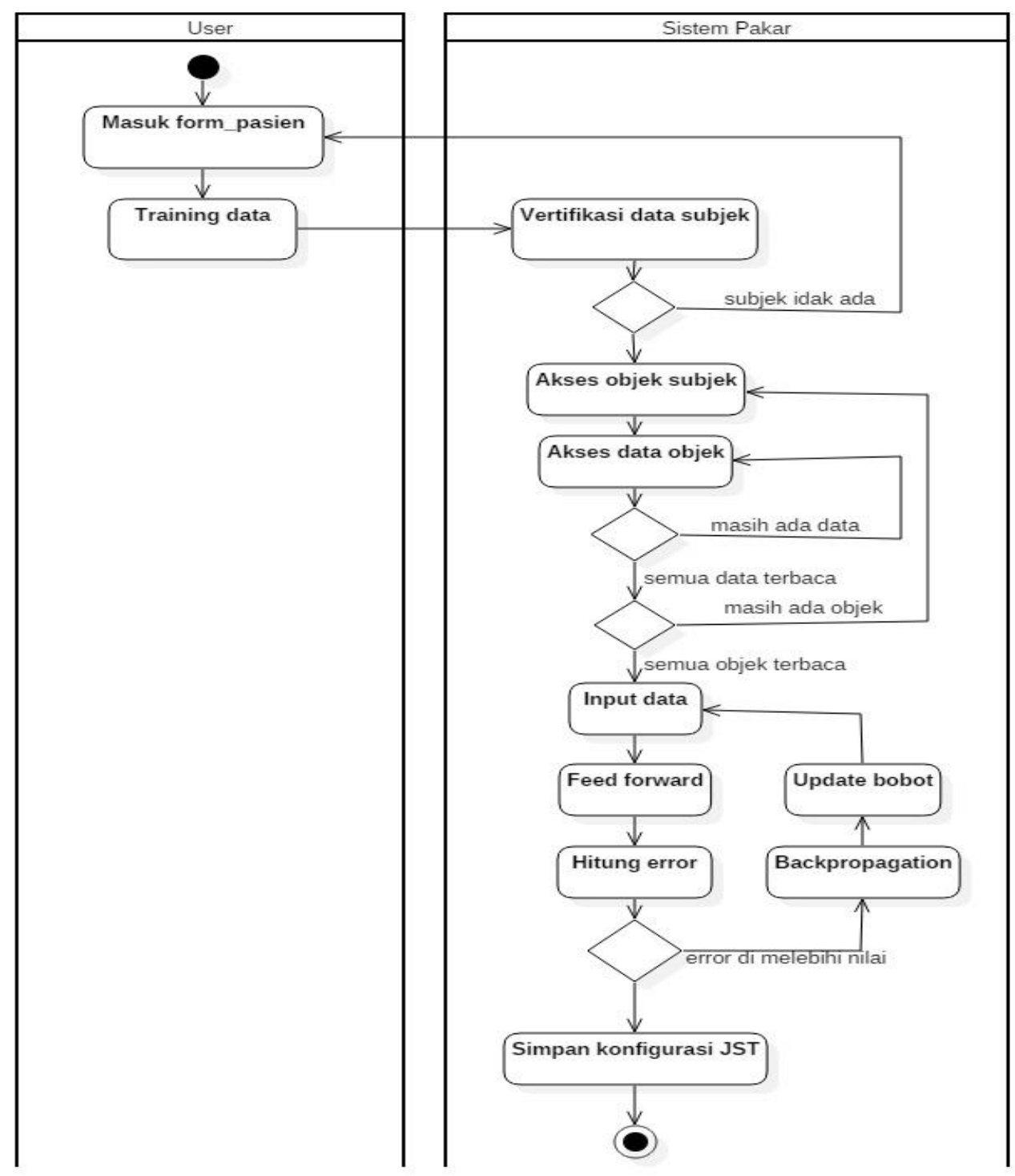

Gambar 5. Activity Diagram Training Data

Gamabar diatas merupakan activity diagram dari training data. Saat user akan melakukan training data, sistem pakar akan memverifikasi keberadaan objek gejala.Setelah itu sistem pakar akan melanjutkan ke dalam jaringan syaraf tiruan (JST) untuk dilatih. Selanjutnya untuk setiap data dan setiap objek akan dimasukkan ke dalam tahap feedforward, backpropagation dan perbaikan bobot secara berurutan. Proses ini berlangsung sampai tercapainya titik konvergen (JST berhasil dilatih).

Backpropagation adalah salah satu metode dari jaringan syaraf tiruan yang dapat diaplikasikan dengan baik dalam bidang peramalan (forecasting). Backpropagation melatih jaringan untuk mendapatkan keseimbangan antara kemampuan jaringan mengenali pola yang digunakan selama training serta kemampuan jaringan untuk memberikan respon yang benar terhadap pola masukan yang serupa namun tidak sama dengan pola yang dipakai selama pelatihan.Untuk arsitektur jaringan syaraf tiruan yang digunakan adalah arsitektur jaringan syaraf tiruan backpropagation. Arsitektur tersebut dapat dilihat pada gambar dibawah ini (Gambar 2) [8]. 


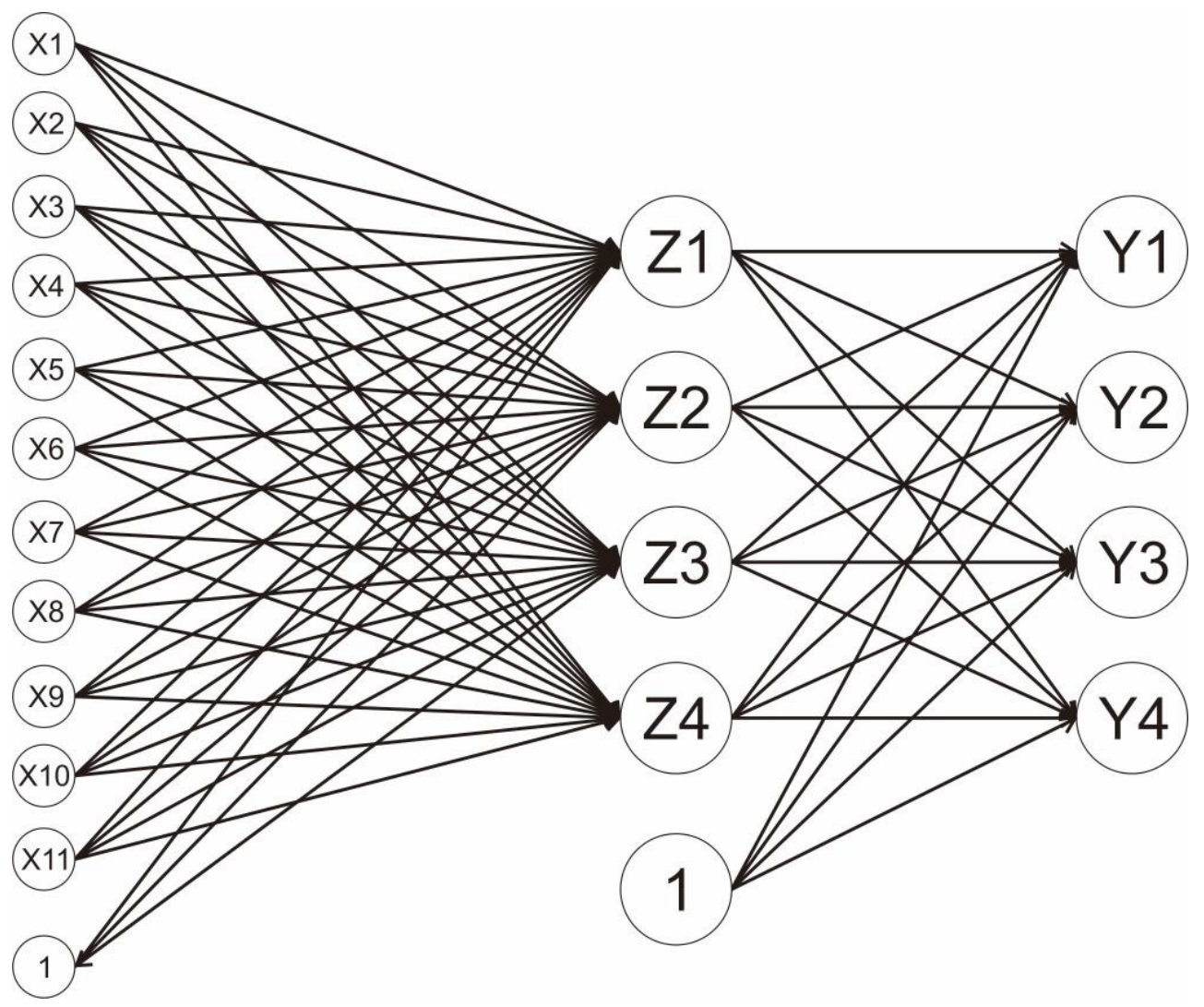

Gambar 6. Arsitektur Jaringan Syaraf Tiruan Backpropagation

Gambar diatas menunjukan $\mathrm{X}$ adalah input layer, $\mathrm{Z}$ adalah hidden layer, dan $\mathrm{Y}$ adalah output layer. Saat sistem pakar menerima data masukan, maka data tersebut akan di masukan kedalam bagian X. Kemudian data tersebut akan dihitung dan dilanjutkan ke hidden layer. Setelah dihitung, maka data tersebut akan masuk ke output layer dan kemudian ditampilkan. Setelah itu, proses backpropagation akan dilakukan. Dimana proses bacakpropagation adalah proses menghitung kesalahan dari setiap layer. Sehingga proses backpropagation akan di mulai dari output layer, kemudian hidden layer, dan terakhir input layer. Setelah proses backpropagation selesai, maka sistem pakar akan merubah bobot tersebut sesuai perhitungan kesalahan backpropagation. 


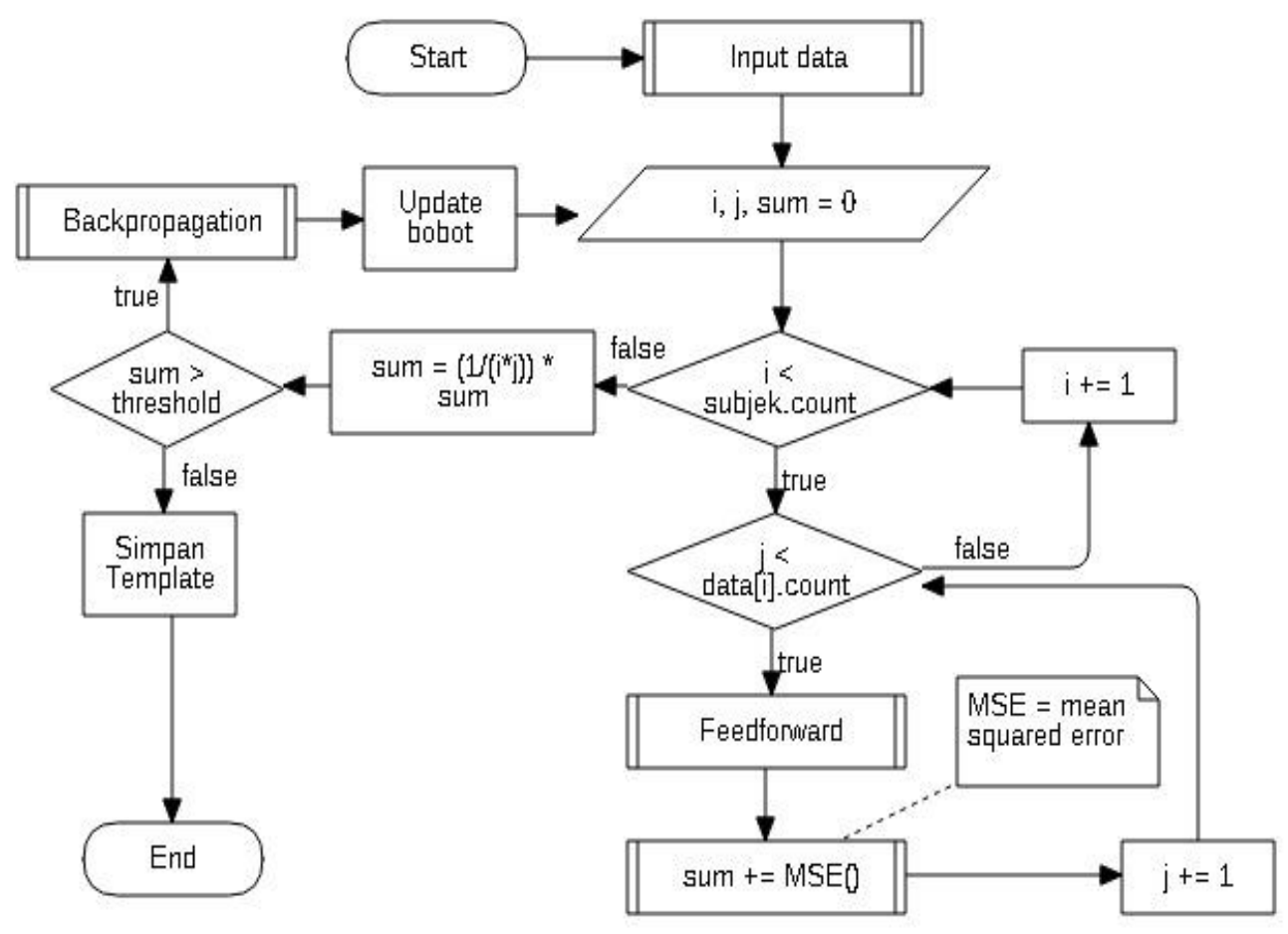

Gambar 7. Flowchart Training Data

Pada gambar flowcharttrainin) (Gambar 3)datadimulai dengan memasukan pola data gejala. Setelah pola data gejala diterima, akan dilakukan propagasi maju dan perhitungn kesalahan. Kemudian dilakukan pemeriksaan nilai kesalahan dari jaringan yang akan dilatih. Jika nilai kesalahan diatas nilai yang telah ditentukan maka akan dilanjutkan ke tahap propagasi mundur. Perhitungan kesalahan yang di lakukan berasal dari masing - masing sinapsis yang menghubungkan antar neuron pada jaringa syaraf tiruan (JST) yang dilatih. Perhitungan ini akan menghasilkan nilai perubahan bobot yang perlu dilakukan pada setiap bobot yang ada dan dapat dilanjutkan dengan proses perbaruan nilai bobot. Jika nilai kesalahan berada dibawah nilai maka konfigurasi jaringan akan disimpan. 


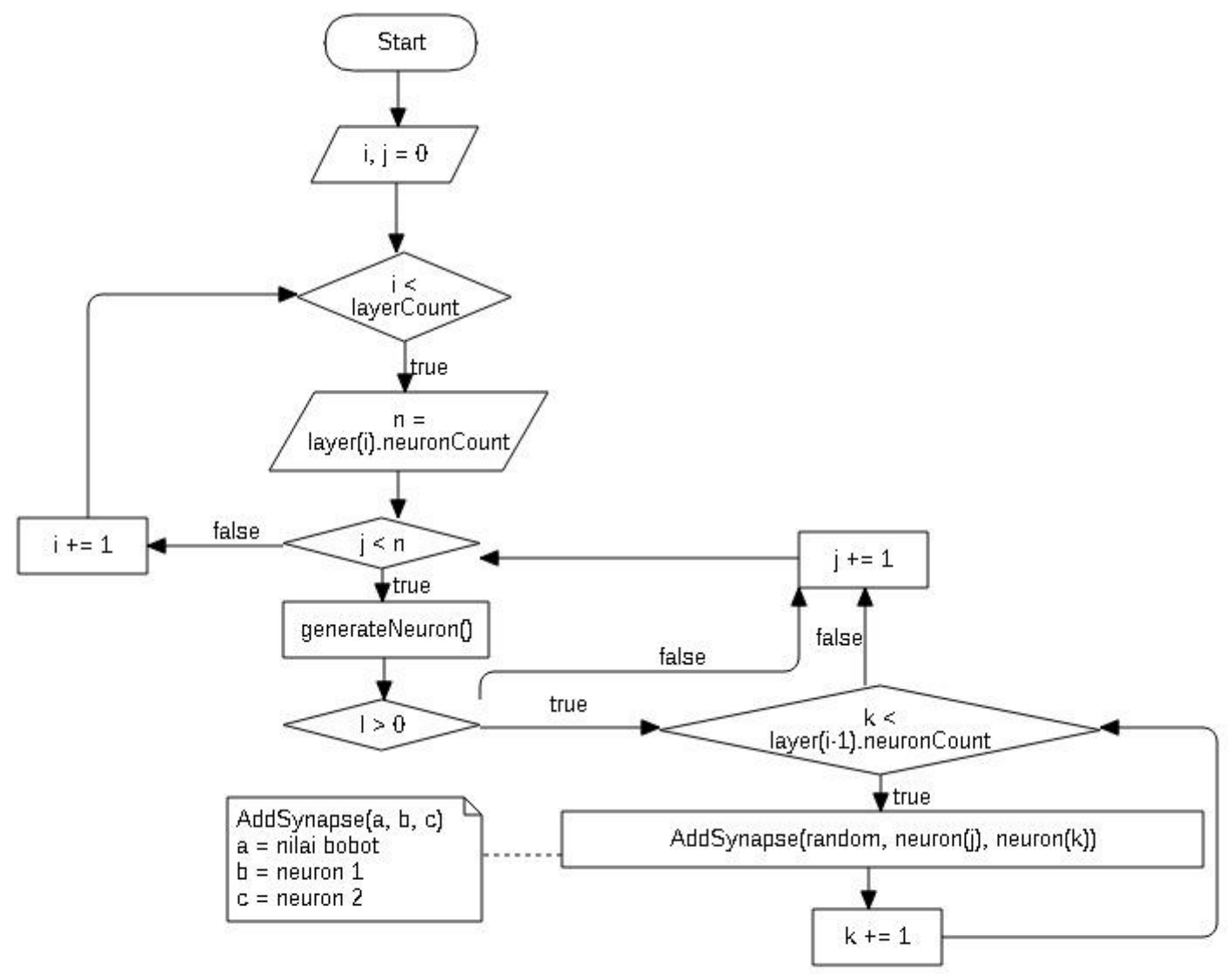

Gambar 8. Flowchart Inisialisasi JST

Pada gambar diatas merupakan flowchart inisialisasi jaringa syaraf tiruan (JST) (Gambar 4). Dalam inisialisasi jaringa syaraf tiruan (JST), sistem pakar akan membagun tiga layer, yaitu input, hidden, dan output. Pertama setiap neuron akan di mulai dari hidden layer yang akan dihubungkan dengan masing-masingneuron pada layer sebelumnya. Neuron tersebut dihubungkan dengan sinapsis yang disertakan dengan nilai bobot awal yang bersifat acak. 


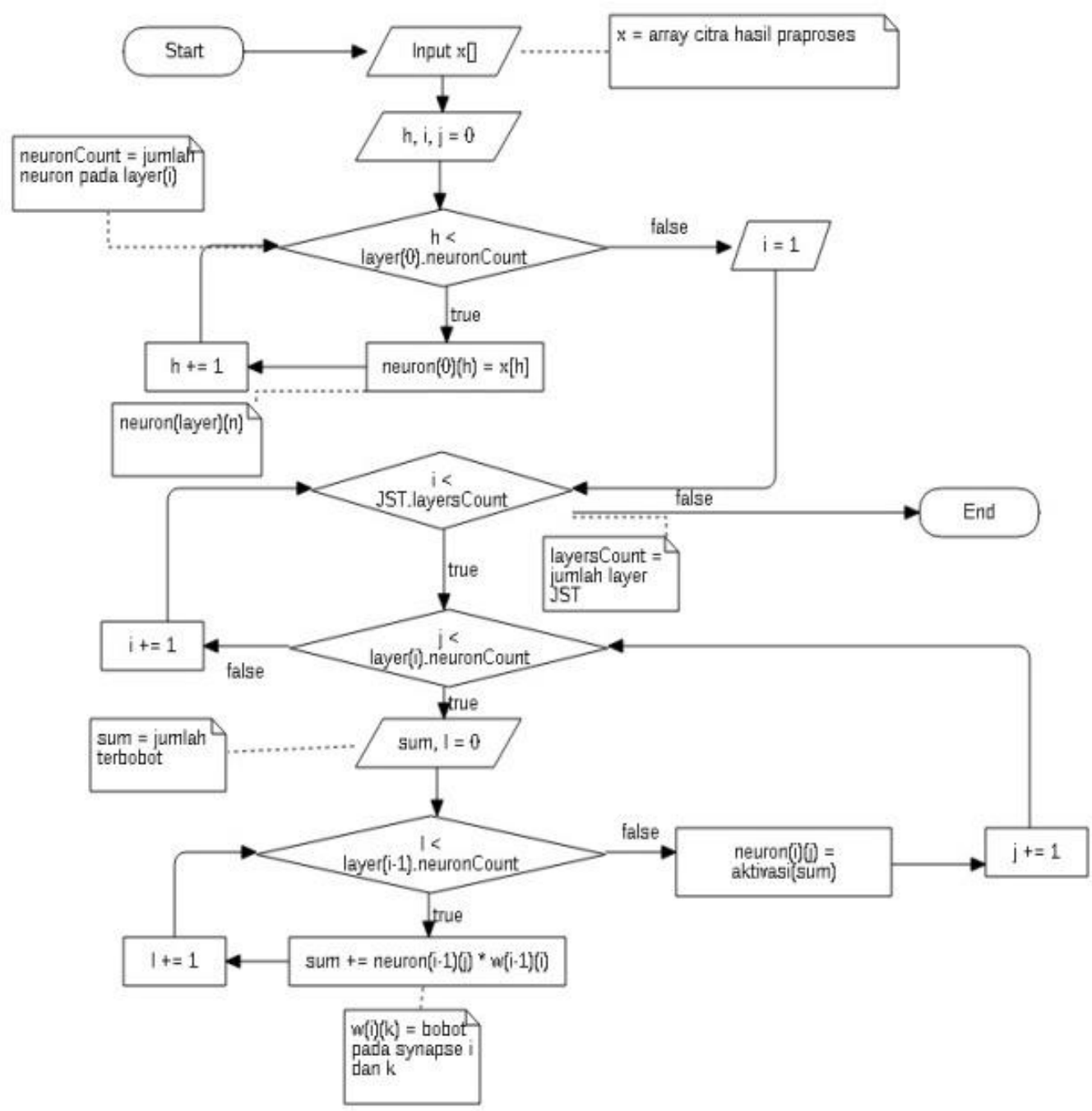

Gambar 5. Flowchart Feedforward

Gambar diatas merupakan flowchart feedforward.Feedforward (Gambar 5)merupakan tahap propagasi maju, dimana setiap neuron masukan akan dilakukan penjumlahan terbobot terhadap masing - masing bobot pada setiap sinapsis yang menghubungkan neuron yang bersangkutan ke layer selanjutnya. Kemudian dari penjumlahan bobot tersebut akan di masukan ke dalam sebuah fungsi aktivasi yang akan menjadi nilai input untuk layer selanjutnya. Proses ini dilakukan untuk setiap layer dan setiap neuron pada jaringa syaraf tiruan (JST) yang sudah dibentuk. 


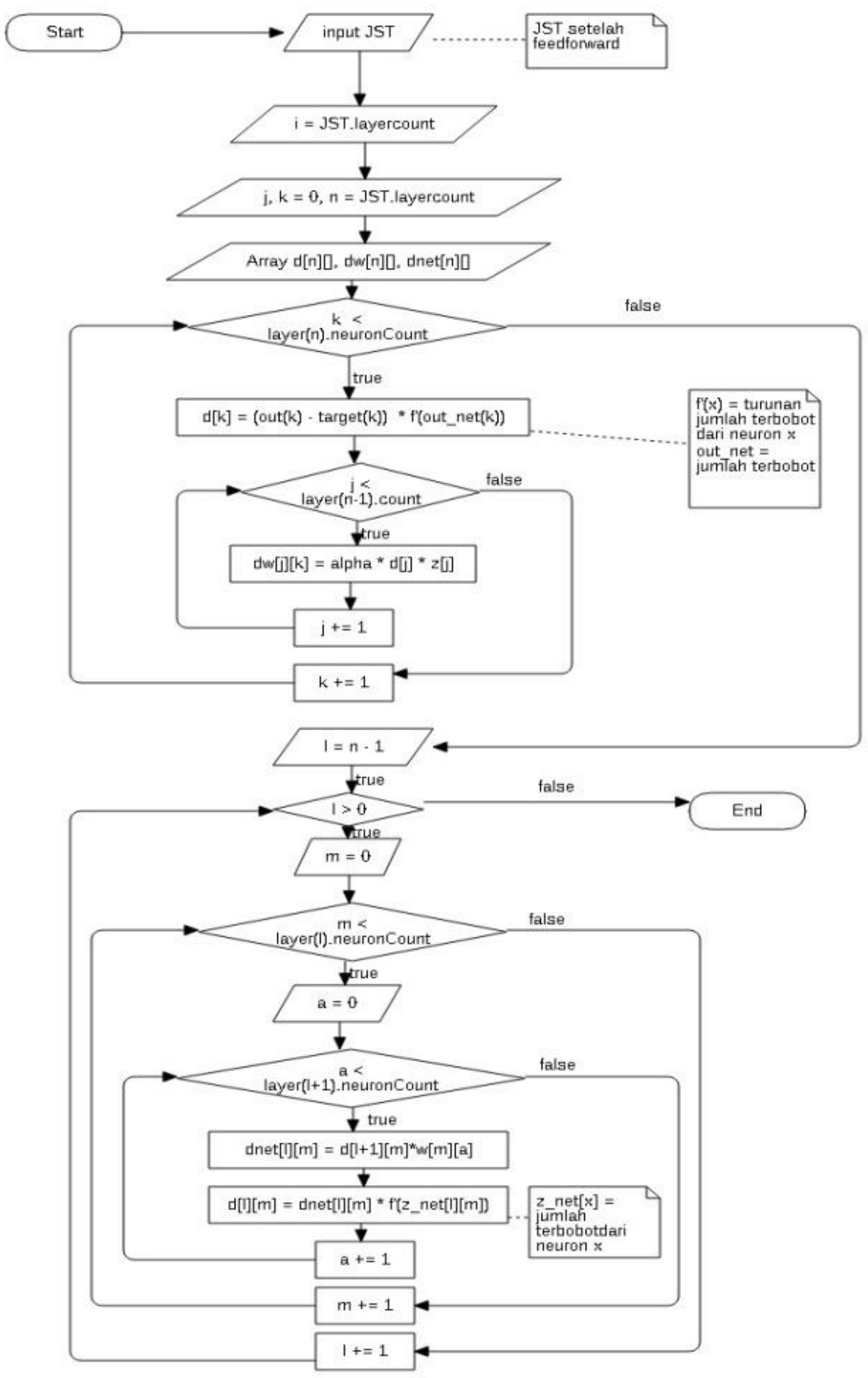

Gambar 9. Flowchart Backpropagation 
Gamabar diatas merupakan flowchart backpropagation (Gambar 6). Backpropagation merupakan tahap propagasi mundur. Backpropagation dimulai dengan perhitungan kesalahan pada layer terakhir atau layer output. Setelah itu akan dicari tanggung jawab dari masingmasing sinapsis yang terhubung atas kesalahan yang terjadi dengan menghitung perubahan bobot yang ada. Proses ini dilakukan secara iteratif terhadap setiap neuron pada masing masing layer dari layer output ke layer input. Hasil tersebut akan digunakan untuk perbaruan nilai bobot pada tahap selanjutnya. berikut [9]:

Secara rinci algoritma pelatihan jaringan backpropagation dapat diuraikan sebagai

Langkah 0 : Inisialisasi bobot (setiap bobot diberi nilai acak antara $0-1$ ).

Langkah 1 : Selama kondisi berhenti belum terpenuhi lakukan langkah 2-3.

Langkah 2 : Lakukan Langkah 3-13 sebanyak jumlah pelatihan yang diinginkan.

Langkah 3 : Untuk output layer dan setiap hidden layer lakukan langkah 4-13.

Langkah 4 : Hitung input setiap node pada hidden layer

Langkah 5 : Hitung output setiap node pada hidden layer dengan fungsi aktivasi.

Langkah 6 : Hitung input setiap node pada output layer.

Langkah 7 : Hitung output pada setiap node pada output layer.

Langkah 8 : Hitung error setiap node pada output layer dengan fungsi deaktivasi.

Langkah 9 : Hitung perubahan bobot pada setiap node pada setiap hidden layer.

Langkah 10 : Hitung error setiap node pada output layer dengan fungsi deaktivasi.

Langkah 11 : Hitung perubahan bobot pada setiap node pada setiap hidden layer.

Langkah 12 : Update bobot pada setiap node pada output layer.

Langkah 13 : Update bobot pada setiap node pada setiap hidden layer.

Setelah pelatihan, jaringan saraf backpropagation diaplikasikan dengan hanya menggunakan tahap perambatan maju dari algoritma pelatihan. Prosedur aplikasinya adalah sebagai berikut (Kusrini, 2008):

Langkah 0 : Inisialisasi bobot (dari algoritma pelatihan).

Langkah 1 : Untuk tiap vector masukan, lakukan langkah 2-4.

Langkah 2 : for $i=1, \ldots$,

Langkah 3 : for $j=1, \ldots, p$ :

Langkah 4 : for $k=1, \ldots, m$ :

Langkah 5: Jika $y_{k} \geq 0,5$ maka $y_{k}=1$, else $y_{k}=0$.

Dari studi kasus dan observasi di dapatkan kesempulan sebagai berikut (Tabel 1):

Tabel 1. Tabel Pola Gejala Virus TORCH

\begin{tabular}{|l|c|c|c|c|}
\hline & Toxoplasma & Rubella & Cyto Megalo Virus & Herpes \\
\hline Batuk & - & $\checkmark$ & - & - \\
\hline Demam & $\checkmark$ & $\checkmark$ & $\checkmark$ & - \\
\hline Flu & $\checkmark$ & $\checkmark$ & - & - \\
\hline Nyeri & $\checkmark$ & - & - & - \\
\hline Mata Gatal & - & $\checkmark$ & - & - \\
\hline Iritasi Kulit & - & $\checkmark$ & - & - \\
\hline Tenggorokan Sakit & $\checkmark$ & $\checkmark$ & - & - \\
\hline Lemah & $\checkmark$ & - & $\checkmark$ & - \\
\hline Lambung Nyeri & - & - & $\checkmark$ & - \\
\hline Pembengkakan & - & - & $\checkmark$ & - \\
\hline Cacar Aie & - & - & - & $\checkmark$ \\
\hline
\end{tabular}


Supaya sistem pakar diagnosa virus TORCH dapat mudah digunakan, maka tampilan sistem pakar ini dibuat seserdehana mungkin. User interface adalah bagian dari perangkat lunak yang dapat dirasakan oleh panca indra pengguna, baik penglihatan maupun indra yang lain.

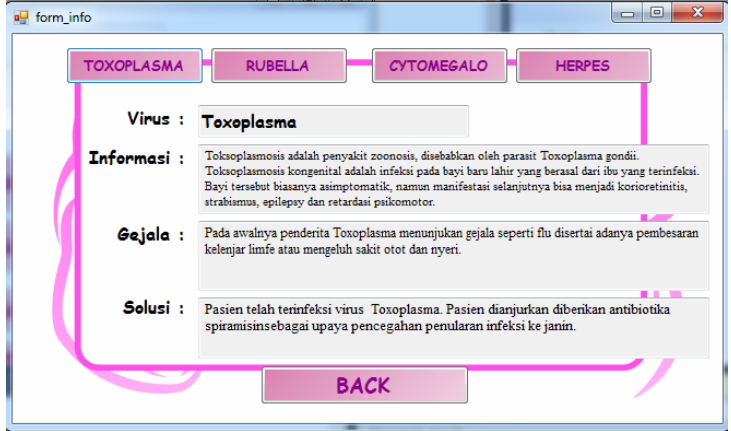

(a)

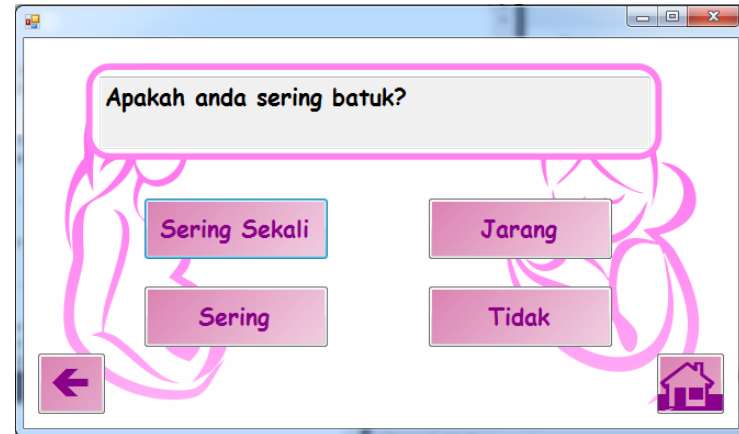

(b)

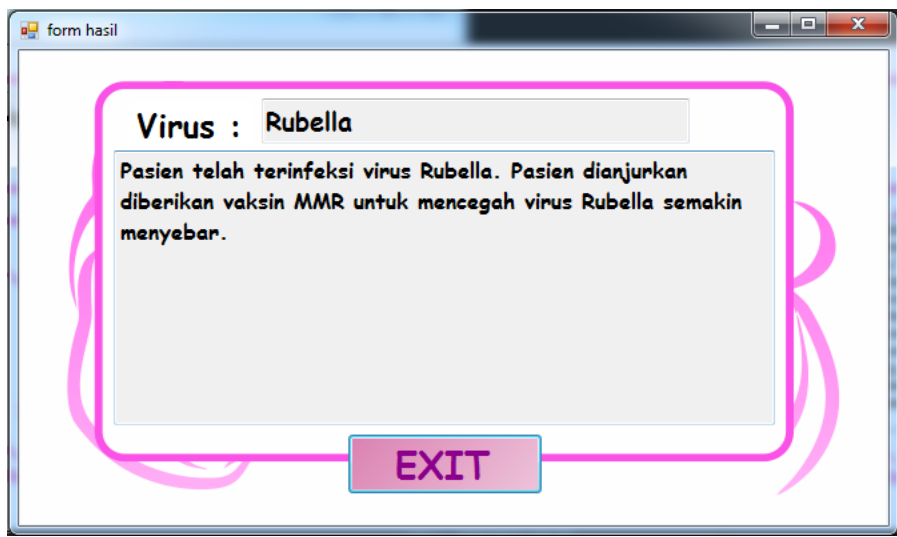

(c)

Gambar 7. Tampilan Halaman (a) form_info;(b) form_diagnosa;(c) form_hasil

Dari gambar di atas dapat di lihat, hasil aplikasi yang dibagun akan tampil user-friendly agar mudah digunakan user. Penerapan sistem pakar dalam mendiagnosa virus TORCH ini dapat membantu penderita dalam mengetahui awal virus TORCH untuk dapat mengetahui bahaya dari TORCH, agar dapat mencegah atau mengurangi resiko anak yang terlahir cacat yang di timbulkan akibat terlambatnya penangganan virus TORCH. Selain dapat melakukan diagnosa dan memberikan nilai kepercayaan serta solusi yang berhubungan dengan virus TORCH, sistem ini juga dirancang untuk dapat menampilkan informasi mengenai virus TORCH serta dapat melakukan penambahan dan pengubahan data mengenai virus TORCH. Penerapan metode forward chaining dan jaringan syaraf tiruan Backpropagation pada aplikasi diagnosa virus TORCH ini dapat mempermudah dan memberikan penyelesaian seberapa pasti user menderita virus TORCH.

untuk pengujian dengan kasus, terdapat 3 ibu hamil yang dijadikan sebagai contoh kasus. Ibu yang pertama adalah ibu Yuli. Ibu Yuli memberitahukan bahwa dia merasa panas demam disertai pilek, nyeri di bagian tangan, sakit tenggorokan, dan mulai merasa lemah. ibu kedua yaitu ibu Desi mengeluhkan bahwa dia merasa demam disertai batuk pilek, matanya mulai gatal tetapi tidak ada debu yang masuk ke mata, kemudian kulitnya mulai gatal seperti terjadi iritasi kulit dan adanya pembengkakan, dan sering sakit di bagian perut di sertai badan 
yang mulai lemah. Ibu yang terakhir adalah ibu Yeli. Ibu yeli menatakan bahwa di seperti terserang cacar air pada saat dia hamil. Dari data diatas, dokter mengatakan bahwa ibu Yuli hanya sakit biasa, sedangkan ibu Desi terinfeksi virus rubella, dan ibu Yeli terinfeksi virus Herpes. Data diatas dapat dilihat pada tabel dibawah (Tabel 2).

Tabel 2. Tabel Data Gejala

\begin{tabular}{lllllllllllll}
\hline Nama & \multicolumn{10}{c}{ Pola Gejala } & \multicolumn{1}{c}{ Virus } \\
\cline { 2 - 13 } & P01 & P02 & P03 & P04 & P05 & P06 & P07 & P08 & P09 & P10 & P11 & \\
\hline Yuli & 0 & 1 & 1 & 1 & 0 & 0 & 1 & 1 & 0 & 0 & 0 & Tidak Sakit \\
\hline Desi & 1 & 1 & 1 & 0 & 1 & 1 & 1 & 0 & 0 & 0 & 0 & Rubella \\
\hline Yeli & 0 & 0 & 0 & 0 & 0 & 0 & 0 & 0 & 0 & 0 & 1 & Herpes \\
\hline
\end{tabular}

Data di atas adalah data berdasarkan bersdasarkan diagnosa dari dokter. setelah data tersebut di ujikan kepada sistem pakar, hasil yang keluar hampir sama dengan diagnosa dokter. data hasil uji sistem pakar dapat dilihat pada tabel di bawah (tabel 3).

Tabel 3. Tabel Data Gejala UserSetelah Diproses

\begin{tabular}{|c|c|c|c|c|c|c|c|c|c|c|c|c|}
\hline \multirow[t]{2}{*}{ Nama } & \multicolumn{11}{|c|}{ Pola Gejala } & \multirow[t]{2}{*}{ Virus } \\
\hline & P01 & P02 & P03 & P04 & P05 & P06 & P07 & P08 & P09 & P10 & P11 & \\
\hline Yuli & $3,6 \%$ & $7,5 \%$ & $8,2 \%$ & $9,3 \%$ & $1,2 \%$ & $4,3 \%$ & $7,9 \%$ & $8,1 \%$ & $1,5 \%$ & $3,2 \%$ & $4,3 \%$ & Toxoplasma \\
\hline Desi & $8,3 \%$ & $9,4 \%$ & $7,9 \%$ & $5,1 \%$ & $7,5 \%$ & $8,2 \%$ & $7,2 \%$ & $3,1 \%$ & $2,1 \%$ & $1,6 \%$ & $2,5 \%$ & Rubella \\
\hline
\end{tabular}

Tabel diatas adalah hasil dari proses diagnosa setelah jawaban user diproses. Pola gejala diambil dari nilai dari paling besar dan telah dibandingkan dengan data di database. Setelah itu, data akan ditampilkan. Dari hasil di atas di dapatkan, bahwa terjadi kesalahan pada ibu Yuli yang tidak sakit tetapi dikatakan sakit oleh sistem pakar. Sedangkan ibu yang lain mendapatkan hasil yang sama dengan diagnosa dokter.

\section{KESIMPULAN}

Hasil sistem pakar diagnosa virus TORCH ini menghasilkan kesimpulan sebagai berikut:

a. Metode jaringan syaraf tiruanbackpropagation dapat diimplementasikan pada sistem pakar yang dibangun menggunakan visual basic.net.

b. Sistem pakar ini mampu mendiagnosa virus TORCH berdasarkan gejala-gejalanya.

Sistem pakar ini dapat digunakan useruntuk melakukan diagnosa virus TORCH tanpa harus betemu dengan seorang pakar.

\section{SARAN}

Ada beberapa saran yang dapat diberikan berkaitan dengan pengembangan asistem pakar ini. Saran untuk penelitian yang ingin melanjutkan pengembangan sistem pakar ini adalah:

a. Pengembangan sistem pakar ini di kemudian hari adalah dapat membuat pilihan untuk menambahkan gejala. 
b. Sistem pakar ini berjalan secara offline, sihingga diharapkan penelitian berikutnya dapat membuat sistem pakar ini berjalan secara online.

Dapat mengembangkan sistem pakar ini dengan menggunakan metode lain yang lebih efektif dan efisien.

\section{UCAPAN TERIMA KASIH}

Penulis mengucapkan terima kasih kepada orang tua dan keluarga yang telah memberikan dukungan baik moral maupun materil kepada penulis untuk selalu berusaha mencapai hasil yang baik. Dan rekan-rekan seperjuangan khususnya di Teknik Informatika angkatan 2013/2014 konsentrasi kecerdasan buatan yang telah memberikan banyak bantuan, dukungan, saran, dan nasehat yang sangat berarti bagi penulis.

\section{DAFTAR PUSTAKA}

[1] Indrawaty, A. Y., Hermana, A. N., \& Ramadhan, A. (2012). Implementasi Model Backpropagation Dalam Mengenali Pola Gambar Untuk Mendiagnose Penyakit Kulit. $J$. Inform, 3(1), 1-7.

[2] Aryasa, K. (2012). Expert System Diagnosa Jenis Penyakit Gigi Menggunakan Jaringan Saraf Tiruan Backpropagation. CSRID, 4.

[3] David, D., \& Kosasi, S. (2013). Penerapan Algoritma Jaringan Saraf Tiruan Backpropagation Untuk Pengenalan Pola Tandatangan. Jurnal Teknologi, 6(2), 139-146.

[4] Mardianto, I., \& Pratiwi, D. (2008). Sistem deteksi penyakit pengeroposan tulang dengan metode jaringan syaraf tiruan backpropagation dan representasi ciri dalam ruang eigen. CommIT (Communication and Information Technology) Journal, 2(1), 69-80.

[5] David, D. (2015). Pengenalan Pola Plat Nomor Kendaraan Menggunakan Jaringan Syaraf Tiruan Backpropagation. Sisfotenika, 3(1), 71-80.

[6] David, D. (2017). Penerapan Jaringan Syaraf Tiruan Perceptron Dalam Sistem Pakar Diagnosa Penyakit Pada Kambing. E-Proceedings KNS\&I STIKOM Bali, 85-90. 